\title{
Integrating Green Practices into Operational Performance: Evidence from Brazilian Manufacturers
}

\author{
Hannah Santos *, Gustavo Lannelongue and Javier Gonzalez-Benito \\ Department of Economic and Business Administration, University of Salamanca, \\ Campus "Miguel de Unamuno" s/n (FES Building), 37007 Salamanca, Spain; \\ lannelongue@usal.es (G.L.); javiergb@usal.es (J.G.-B.) \\ * Correspondence: hannaholiveira@usal.es; Tel.: +32-6679-33503
}

Received: 2 April 2019; Accepted: 17 May 2019; Published: 24 May 2019

\begin{abstract}
The pressures exerted by the market, society, regulators and/or clients on organisational environmental responsibility have required companies to adopt environmental management practices. Within this process, integration with suppliers and customers is important to enable companies to meet these demands, and at the same time achieve their organisational goals. Using empirical results from 117 respondents on Green Supply Chain Management (GSCM) practices among Brazilian manufacturers, we examined the impact of the adoption of green practices on operational performance. To do so, we developed a questionnaire to collect the variables on environmental practices and operational performance in manufacturing firms in Brazil, an emerging economy in which this sector accounts for $25 \%$ of its Gross Domestic Product (GDP). The results show that the adoption of GSCM between suppliers and/or customers has a positive effect on operational performance. This means companies can benefit from a green supply chain by cooperating with upstream suppliers of environmentally responsible production technology and by exchanging environmental information with them, as well as considering the views of customers and green consumers in their production processes. This study provides empirical support for managers promoting environmental practices that may lead to operational performance and sustainable growth.
\end{abstract}

Keywords: Green Supply Chain Management practices; integration practices; operational performance

\section{Introduction}

For a long time, Supply Chain Management research had focused on coordinating interdependent processes, information and knowledge to meet specific objectives, giving little attention to different methods of coordination and possible interactions with those involved along the Supply Chain (SC) [1]. However, in recent years, growing global competition has driven companies to address a systematic view of Supply Chain Integration (SCI), leading them to reconsider the need for mutually beneficial cooperative supply partnerships, prioritising the joint improvement of inter-organisational processes [2-4].

Coordination among SC members as suppliers and customers is the key to achieving the necessary flexibility to enable them to progressively improve. For example, effective collaboration is likely to lead to improvements in the logistics and new product development processes in response to rapid market changes [5], allowing firms to obtain greater operational performance, avoid waste and use resources more efficiently. On the other hand, ineffective coordination between members of the SC system can lead to many negative consequences, such as higher inventory costs, longer delivery times, higher transportation costs, poorer customer service, higher levels of loss and damages, and consequently, a greater environmental impact $[1,6]$, which in turn can have a negative effect on firms' operational performance. 
In order to avoid these issues, organisations have adopted an approach oriented towards external relations, including the application of environmental management principles to the SC $[7,8]$. In this context, organisations are expected to expand their sustainability efforts to integrate their green practices with those of their suppliers and meet the sustainability expectations of both their suppliers and customers for a greener SC and sustainable competitive advantage [9]. This is the idea behind Green Supply Chain Management (GSCM), which calls for practices that require closer coordination with immediate customers and/or end consumers, as well as between companies and their suppliers when designing and developing products [8] in order to facilitate the achievement of organisational environmental objectives.

Although the importance of green practices for organisational performance is widely acknowledged [8-11], there is no consensus on the measures that should be used to integrate green practices with suppliers and customers. There are measures in the literature related to integration with suppliers and customers that do not consider environmental factors [9] and other measures that consider integrating green practices with suppliers and customers separately [10]. Procedures that observe the effect of these practices individually provide a limited view of how integration works, as the SC system, involves a number of actors that cooperate to achieve specific logistical and strategic objectives [12]. In this paper, we develop a procedure that contributes to the existing measures considering environmental factors that are not covered by the measures used in literature for green practices; thus, this paper serves as a basis for future research on companies' integration with suppliers and customers. We posit that the adoption of practices in a balanced way with suppliers and customers can provide a broader view of how integration with suppliers and customers can impact organisational performance.

This study seeks to explore the adoption of integration green practices in Brazil, which provides a setting with at least some particularities. The first concerns the implementation of the National Solid Waste Policy (PNRS) in 2010, which establishes the shared responsibility in waste generation to manufacturers, importers, distributors, traders, citizens and owners of management services with regard to packaging and reverse logistics. This provides an attractive environment for the study of green practices developed within the organisational scope [13]. Furthermore, Brazil is an emerging economy that is now the world's ninth largest economy [14]. Despite its significance, it is still an understudied country in operations management. In addition, [15] upon reviewing the latest Latin American publications on SC sustainability, the publications highlight the need to improve the visibility of research in Latin America and foster the development of research in this region, enabling academics to make more reliable recommendations for practitioners and policymakers [16].

In this study, we develop a comprehensive model that integrates constructs used in prior works $[11,17,18]$ with empirical evidence on the adoption of green practice in the SC and operational performance. This is essential because the development of reliable and valid measures is indispensable for contributing to the legitimacy and the progress of a research field. Therefore, this scale development aims to sharpen the concept of GSCM and improve our understanding of this topic.

Unlike most previous surveys that have addressed the impact of different green practices in isolation with suppliers or customers, the present study examines the combined effect of various green practices performed with suppliers and customers on organizational operational performance within a geographic context still in development, Brazil. This provides new insight into the environmental literature and addresses a recent research call on understanding the nexus between joint integration and operational performance in an emerging economy, taking into account the importance of a balanced relationship with suppliers and customers in order to achieve organizational objectives. In addition, the main contributions of this study are directly related to the availability of information about the environmental practices carried out by the companies analysed and the actions elaborated based on the results of the research to improve the environmental management of the companies surveyed, through the managerial implications and impacts for the sectors studied. 
This paper is divided into six sections: Section 2 presents the arguments that support the hypotheses proposed; Section 3 presents the methodology used; Sections 4 and 5 are dedicated to the results and the discussion; Section 6 presents the managerial implications; Section 7 is devoted to the impacts for the sectors studied, and finally, Section 8 presents our conclusions, including directions for further research.

\section{Literature Review and Hypotheses}

\subsection{Integrating GSCM Practices with Suppliers and Customers}

The literature on sustainability is relatively well-developed and incorporates economic, social and environmental concepts [19]. The focus in this work is on the environmental component of sustainability, specifically on green practices developed in the SC. Reference [20] described the management of the GSCM as the integration of material and information flows throughout the SC to satisfy customer demand for green products and services produced by green processes. Reference [8] argued that environmental integration focuses on inter-organisational interactions between SC members, including aspects such as joint environmental goal setting, shared environmental planning, and working together to reduce pollution or deal with other environmental issues. This integration also includes the exchange of technical information, and requires a mutual willingness among manufacturers, suppliers and customers to learn about each other's operations to plan and set environmental improvement goals. It also implies cooperation to reduce the environmental impact associated with material flows in the SC and a good understanding of the responsibilities and capabilities involved in environmental management [21].

According to [22], GSCM practices should cover all SC activities, from green purchasing to integrating lifecycle management, through manufacturers and customers, to the close of the cycle with reverse logistics. Several product-level green practices are described in the literature, including eco-design [7,8], product recycling design [23], reduction of carbon emissions in logistics activities [24,25] and reverse logistics [26-28].

The proposed green practices are implemented at two levels of SC analysis: firstly, green practices developed upstream; these practices are directly associated with the interactions between a company and its suppliers, involving environmental concerns. Supplier integration involves coordinating and sharing information with key suppliers that provide the company with insight into supplier processes, capabilities and constraints. These suppliers also enable more effective planning and forecasting, the development and process of eco-design, design for product recyclability [29]. Secondly, green practices implemented downstream; these practices are those that incorporate environmental concerns into all types of flows (materials and information) between companies and their downstream partners involved in the delivery activity. Customer integration refers to collaborative efforts and the exchange of information with key customers that provide the company with a strategic view of market expectations and opportunities, enabling a more efficient and effective response to be made to customers' demands for green products $[30,31]$. In this study, integrated GSCM practices are considered to be any action carried out throughout the SC involving relationships with suppliers and customers to eliminate or reduce any type of environmental impact the activities may generate.

The definition of GSCM can be understood from the following dimensions: internal environmental management, green purchasing (supplier), customer cooperation including environmental issues, eco-design and investment in material recovery. In the latter case, suppliers can also operate using recyclable products [32].

In light of this, integration with suppliers and customers plays an important role for those organizations that seek to manage the supply chain in a sustainable way; this means the transfer and dissemination of knowledge about environmental issues among them is crucial. For example, effective integration can be achieved through packaging in partnership with suppliers or designing products in partnership with customers, with emphasis on minimizing the generation of waste and the 
environmental impact of the product throughout the life cycle. In other words, when the supplier's understanding of environmental responsibilities is aligned with the customer's, the organization is more likely to achieve environmental objectives, thereby achieving operational and financial benefits.

The following sub-section contemplates the argumentation of the hypotheses formulated here.

\subsection{The Impact of the Adoption of Environmental Management Practices with Suppliers and Customers on Operational Performance}

Due to increased public awareness and stakeholder pressure, existing business relationships are likely to be leveraged to address environmental issues [28,33]. It is intuitive that solving environmental issues in a collaborative way can be faster, cheaper and more effective if companies can draw upon established communication structures, common knowledge and integrated, reliable and proprietary technologies $[34,35]$. Therefore, relations between companies can be interpreted as the capability that facilitates, or at least involves, an extension of collaborative efforts towards environmental issues. In addition, GSCM practices can be identified within an alliance as an opportunity to address business challenges. Collaborative capabilities such as organisational learning and risk acceptance may be important requirements for the successful implementation of environmental practices [36].

Even though most collaborative efforts typically aim to improve industrial performance, inter-firm relationships have proven environmental benefits [37]. Companies often present these improvements as the unintended consequences of broader collaborative efforts. This is because collaboration can expose companies to new opportunities and facilitate the diffusion of knowledge in solving problems between the parties involved. Other research finds that supplier relationships help the adoption of innovative environmental technologies [38]. For example, companies take specific measures, such as re-designing products and production processes, with the help of SC partners [34]. These common efforts streamline solutions, reduce costs and can lead to increased productivity, improved environmental performance and growth [39].

The practices considered in this work involve understanding the environmental responsibilities among the SC's stakeholders, working together to reduce environmental impact, the requirement of environmental certification, the exchange of technical advice to meet the environmental criteria required by society, regulation, customers, etc. and the required use of environmentally responsible packaging, with the rationale of the hypotheses considered here being based on them.

The first practice that we use to measure GSCM involves understanding the environmental responsibilities among SC partners. Companies cannot achieve their environmental goals and objectives without involving them in the SC, and it is not feasible to concentrate internally on improving environmentally responsible processes while their suppliers provide harmful materials [22]. As a possible feature, Reference [8] established the mentoring approach based on collaboration and a close relationship between suppliers and customers. This approach focuses on supplier education and training, involving them in product design to consider environmental requirements, and providing them with financial assistance to improve the performance of their processes, equipment and materials [40]. Reference [8] suggested that the monitoring approach requires time and fewer resources, but this does not allow or verify the actual sustainability of suppliers' performance.

The second practice considered concerns the joint work to discover forms of environmental prevention in the productive process and may involve the awarding of prizes and incentives to SC employees and partners. Alcoa (Pittsburgh, Pennsylvania), for example, offers rewards and incentives to its employees in factories around the world to work with community groups on innovative ways to preserve the natural environment and resolve environmental problems [41]. Sony (Mexico City, Mexico) has rewarded employees at facilities in Mexico to find alternative ways to transport waste from production sites to landfills and develop recycling systems that reduce the amount of waste to be disposed of by other means. Ford (Michigan, EUA) has also worked closely with more than 40 suppliers in 40 developing countries on its Partnership for a Clean Environment (PACE) and aims 
to follow best practices to reduce waste, carbon dioxide and atmospheric emissions. Consequently, global carbon emissions could be reduced by almost 500,000 metric tons over the next five years [42].

SC's environmental certification requirement is the third practice considered in the study and reflects the entire chain's commitment to continuously improving the organisation's environmental impacts and to the extensive knowledge and monitoring of organisational resources, constraints, production capacities and processes [43]. By adopting an Environmental Management System (EMS), the company not only focuses its attention on negative environmental impacts, but also ensures that responsibility is duly assigned to the maintenance of high environmental standards throughout the organisation [44]. Many companies believe that the implementation of environmental certification programmes can lead to a better corporate image and generate a competitive advantage [45]. This is usually achieved by using eco-labels on the company's products, allowing the product to stand out as being produced in an environmentally sound manner. Eco-labels associated with environmental certification inform consumers that the product in question has been verified by an outsourced auditor as originating from an environmentally well-managed company [46]. Therefore, the certification gives an indication of good practice and provides the company with a better image. This approach allows consumers to target their buying behaviour in an eco-friendlier way [47].

The fourth practice, defined as the exchange of technical advice to meet environmental criteria, favours the importance of including technical teams capable of providing adequate training in the environmental criteria required by their partners. For example, Texaco (New York, EUA) deploys managers and technical staff for training its business partners and affiliates' employees in developing countries in sound green practices. Samsung (Seoul, South Korea) has decided to seek collaboration based on the combination of criticality and supplier size. It has recognised its limited capabilities in environmental management, and instead of forcing suppliers to comply with the Restriction of Certain Hazardous Substances (RoHS) Directive, it has provided technical and managerial assistance. These initiatives include environmental training, education and technical support for analysing material compositions. The joint work has also been carried out with welding suppliers to develop lead-free soldering processes. As a result, Samsung and its supply chain were able to meet the environmental demands of Original Equipment Manufacturer (OEM) customers one year before the deadline set by the regulations [48].

The fifth and final practice considered here is the requirement for partners to use environmentally responsible packaging. The studies by [49] and [50] consider packaging as one of the key elements that underpin efficient GSCM. For packaging to be considered eco-friendly, it must have a minimal impact on the environment during its lifecycle (from the manufacture of packaging by suppliers to recycling with customers through reverse logistics). The use of eco-friendly packaging has remarkable benefits in terms of reducing carbon emissions, as it is made from biodegradable and recyclable materials, reducing the consumption of natural resources in the production process; ease of disposal; improving the company's image, because the use of recyclable materials throughout the production process reinforces the notion that the company is environmentally responsible and willing to care for the environment. The company will also benefit in terms of costs, as packaging will cost less due to the use of natural resources [50,51]. All these activities related to SCM require high degrees of interaction with other organisations in the SC, whether upstream with suppliers or downstream with customers [8].

Previous research has empirically addressed the importance of developing sustainable SC management with suppliers and customers. Reference [52] found that the practices of reverse logistics, waste reduction and ISO 14001 are crucial for an SC to be considered green. Similarly, Reference [11] suggested that the implementation of sustainable practices leads to improved environmental performance as measured by reductions in air emissions, effluent waste, solid waste and the consumption of toxic materials. Reference [53] stated that sustainable purchasing has a positive effect on economic, social and operational results, while sustainable packaging has a positive effect on environmental, economic and social results. Reference [54] indicated that prevention of pollution and green supply management are the main forces that lead to financial performance, 
and green product development appears to be acting in a secondary way in this relation. Additionally, they found that the adoption of ISO 14001 is not directly related to the financial performance of a company. Reference [55] suggested that suppliers with greater information sharing capacity have improved their environmental collaboration, contributed to ecological cost savings and attained a competitive advantage. Furthermore, Reference [56] showed that integration with suppliers and development of green sustainability programs can significantly improve the financial performance of fashion companies.

The above studies-in addition to other studies dealing with the relationship between green practices and organizational performance-have made major contributions to SC's sustainable management area; however, such studies do not consider the effect of environmental management practices developed in conjunction with suppliers and customers. In this way, we contribute to the literature by constructing a comprehensive model that encompasses constructs used in other investigations $[9,11,17]$, providing empirical evidence in the context of six sectors of manufacturing industries in Brazil.

Although there are many studies that focus their research on proving the impact between green practices and organisational performance, few studies consider how the joint adoption of green practices with suppliers and customers impacts on operational performance [8]. This work addresses the measures for GSCM practices used in the literature and tests the impact the joint adoption of green practices with suppliers and customers has on organisational performance. In turn, when green practices are developed in a balanced way with suppliers and customers, they also benefit the organisation. Based on the above arguments, we have formulated three hypotheses to test the impact of GSCM practices on operational performance.

Hypotheses 1 (H1). Green practices developed with suppliers have a positive impact on operational performance.

Hypotheses 2 (H2). Green practices developed with customers have a positive impact on operational performance.

Hypotheses 3 (H3). Green practices developed balanced up-down with suppliers and customers have a positive impact on operational performance.

The research structure, shown in Figure 1, is developed to investigate the relationships between five GSCM practices that Brazilian companies may implement to improve their performance, namely, mutual understanding of responsibilities regarding environmental management, working together with partners to reduce the environmental impact of products and activities, requiring partners to have environmental certifications, sharing environmental technical advice with partners to meet environmental criteria and requiring partners to use environmental packaging. The practices, dimensions and items used here are based on previous literature that addressed several elements of $\operatorname{GSCM}[9,11,17]$. 


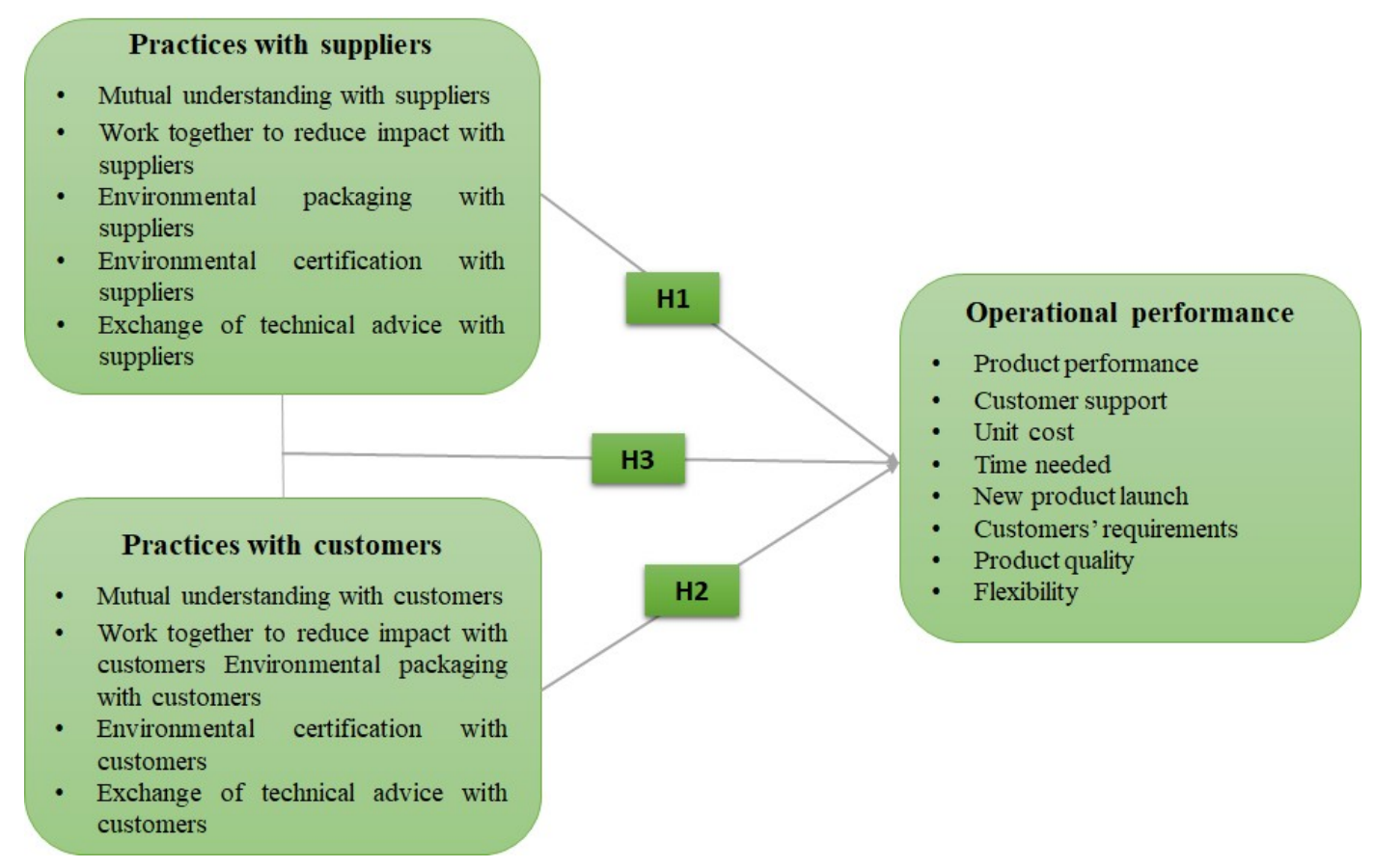

Figure 1. Research framework for studying the relationship between Green Supply Chain Management (GSCM) integration practices and performance in Brazilian manufacturing firms.

\section{Materials and Methods}

The model of GSCM practices is theorised, and the constructs included in the model are defined according to the literature on the management of manufacturing operations. Considering this manufacturing focus, data were collected from a sample of factory-level managers in Brazilian manufacturing firms.

This data collection process was managed by the Qualtrics (Online software for creating, distributing, and processing responses and data.) software, online data service, from June to August 2017, and was structured to ensure unique responses from validated manufacturing panel members. With regards to the application, we followed the methodology presented in [56]. The Brazilian database available for the gathering of financial information contained only the companies listed on the Brazilian Stock Exchange, and this did not reach the minimum number of the population of Brazilian manufacturing companies required. Therefore, the researchers looked for alternative ways of identifying which manufacturing industries would fit the study. Through the Digital Media Information Services Limited Partnership (Ltd.) (São Paulo, Brazil), a professional association that publishes online balance sheets, with more than 10,000 registered companies, we selected the sectors of interest based on those sectors that contribute most to the country's Gross Domestic Product (GDP). From this information, we communicated with production managers via electronic correspondence. We initially contacted each production manager in the listed companies by telephone to establish a link between evaluator and respondent, clarifying the purpose and importance of the research, and thus motivating the potential respondent. If the person agreed to take part, we asked for their e-mail and sent the questionnaire along with a cover letter, in which we sought to emphasise certain points, such as the importance of the project for the development of the Brazilian manufacturing sector, and the importance of each respondent's participation and the estimated time required to effectively respond to the questionnaire, with a full assurance of confidentiality in data processing. A pre-test was also conducted to modify the questions that were not clear or that could be misinterpreted. To do this, we sent the questionnaire to two companies included in the initial sample and to four prestigious scholars. The total population of companies included in these sectors is 725 . We received 160 questionnaires, of which 43 were unusable due to the high amount of missing data. Finally, 
117 valid responses were obtained (17.65\%), with this response rate being considered normal in studies that use questionnaires as a source of data collection [57].

The sectors chosen were classified according to the North American Industry Classification System (NAICS), which is the standard used by federal statistical agencies in the classification of commercial establishments. The sectors used in this research are food and kindred products (NAICS 20), textile mill products (NAICS 22), chemicals and allied products (NAICS 28), rubber and miscellaneous plastics products (NAICS 30), primary metal industries (NAICS 33) and fabricated metal products, except machinery and transportation equipment (NAICS 34). Table 1 shows the overall population of companies by sector and the final sample used in the study.

Table 1. Initial and final sample distribution of companies by sectors.

\begin{tabular}{ccc}
\hline Sector & Population (\%) & Final Sample (\%) \\
\hline 20-Food and kindred products & $161(22.21)$ & $18(15.4)$ \\
22-Textile & $133(18.34)$ & $13(11.1)$ \\
28-Chemicals products & $71(9.79)$ & $25(21.4)$ \\
30-Rubber and plastic products & $89(12.28)$ & $20(17.1)$ \\
33-Primary Metal & $78(10.76)$ & $13(11.1)$ \\
34-Fabricated Metal & $193(26.62)$ & $28(23.9)$ \\
Total & $725(100)$ & $117(100)$ \\
\hline
\end{tabular}

\subsection{Measures of Variables}

\subsubsection{Dependent Variables}

a) EM practices with suppliers and EM practices with customers

A scale was constructed by asking the respondent to extend the environmental activities to their suppliers and another similar scale was constructed asking the respondent to extend the environmental activities to their customers. A total of five items were developed and these were adapted from the literature to achieve symmetry upstream and downstream of the supply chain (see Table 2). A Likert scale from 1 to 5 was used for each item, with the minimum value (1) referring to total disagreement with the proposed statement and the maximum value (5) referring to total agreement with the statement. It should be noted that all the scales were reported from the point of view of the production manager (e.g., we have developed a mutual understanding of responsibilities regarding environmental management with our partners). Obtaining the measure for the variable EM practices with suppliers and for variable EM practices with customers came by means of the average response of the items.

b) Control Variables (CV)

Number of customers. This variable indicates the number of active customers the company has. It is a question in which the respondent had four answer options: fewer than 15; between 16-30; between 31-45; more than 45 customers. Values from zero to four were assigned to the responses received and treated as a continuous variable.

- Number of suppliers. This variable indicates the number of active suppliers the company has. It is a question in which the respondent had four answer options: fewer than 15; between 16-30; between 31-45; more than 45 customers. Values from zero to four were assigned to the responses received and treated as a continuous variable.

- Time. The respondent was asked how long they had been working in the company, having four options: less than 2 years; between $2-5$ years; between 6-10 years; over 10 years. This question is important to know the respondent's experience in answering questions about the company and the practices developed in it. 
- Positioning in the supply chain. This is a question in which we asked the respondent about the value perspective of the chain that fits their company's situation. This question had four answer options: we sell end-products directly to consumers; we sell end-products to other intermediaries, who are selling to end-consumers; we sell products that are components/parts of other end-products; we sell products to other manufacturers, who sell their products/components or other end-products. Each item was used separately as a dichotomous variable that assumes a value 1 if the company fits the variable and 0 if not.

- $\quad$ Firm size. As discussed in other studies, total company assets were used to measure the size variable. These data were obtained manually from the balanced sheets available online.

- Industry type (sectors). NAICS codes were used to control for industry effect.

c) Balanced up-down EM practices

The joint measurement of practices with suppliers and customers is defined as balanced up-down EM practices; it captures the balanced adoption of green practices developed with suppliers and customers. The items used for green practices are based on previous literature [10], but for the joint analysis of the integrative practices developed between company and suppliers and customers, we have constructed a measure for jointly capturing the developed practices. To create this measure, defined as a balanced adoption between suppliers and customers, we followed these three steps:

Step 1-Sum of the scores recorded by practices with suppliers and practices with customers. The first step in constructing the measure for integrating the practices was the sum of the scores obtained in each item, for both supplier and customer. However, the sum of the items does not clearly represent how the practices are being developed, to perform more than the sum of the scores obtained to consider the practices with suppliers and customers. For example, the scale had a maximum score of 5 (totally agree). If the respondent scored 5 for the practices with customers and 1 for the practices with suppliers, the sum of 6 did not reflect the integration or how the practices are being developed, as response 1 reflects that they do not develop and the response they develop. Therefore, Step 2 becomes necessary.

Step 2-Equilibrium of the adoption of practices with suppliers and customers. In this step, we attempted to find the balance between responses to suppliers and customers by taking the absolute values of the differences in the responses of items with suppliers and customers and decreasing the maximum value of the Likert scale (see Formula). The maximum values that can be reached in this step are 5 (Likert scale), whereby practices are being developed in a balanced way, and 1 , which shows the practices are not being developed in a balanced way.

Step 3-Integrated practices with suppliers and customers. After having created the two measures in the previous steps, we added the two together to create a third measure that we call integrated practices. The value range that the measure found in Step 3 assumes is a minimum of 7 and a maximum of 15 .

$$
\begin{gathered}
\text { Suppliers practices }+ \text { Customers practices } \\
5-[(\text { Suppliers practices - Customers practices) }] \\
\text { Balanced up-down EM practices }(3)=(1)+(2)
\end{gathered}
$$

Each item represents a practice performed by the company, which may properly develop two, or more or none. The mean of the five items was used to represent each practice. If we consider the joint measure as the sum of each practice's responses to suppliers and customers, we would not know how each practice is developed. For instance: to the question on the mutual development of the understanding of environmental management responsibilities among the SC's partners, the respondent that agrees with the affirmation, option number 4, regarding suppliers, and does not agree with the affirmation, option number 2, with respect to customers, it would add up to 6 if we were to consider the sum of the two answers, and we would not know how to state how they are being developed (Step 1). 
In calculating Step 2, our goal is to find the balance between respondents' answers. In the example, the result is 3, which would be the inclusion of the responses in Formula (2) $\{[5-(4-2)]\}$. In Step 3, we have added the two previous steps together to distribute the weights assigned to supplier practices and customer practices. In the end, we define the values found as a measure of integrated practices.

The scales we used to measure integrative practices with suppliers and customers meet the assumptions of reflective scales [58]. Deleting an item does not necessarily indicate that the company does not perform a practice.

The confirmatory analysis verifies that the coefficients of the items were satisfactory for both practices with suppliers and for customers (Table 2). The goodness of fit measures were also satisfactory: for suppliers: $\chi^{2}=5.864(p=0.210)$, Chi Square/Degree Freedom $\left(\chi^{2} / \mathrm{DF}\right)=1.466$, Goodness of Fit Index $(\mathrm{GFI})=0.980$ [criteria [59] $>0.9$ ], Adjusted Goodness of Fit Index (AGFI) $=0.925$, (TLI) $=0.988$ (criteria $>0.9)$, Normed Fit Index $(\mathrm{NFI})=0.995($ criteria $>0.9)$, Root Mean Squared Error $($ RMSEA $)=0.063$ (criteria < 0.08); and for customers: $\chi^{2}=11.021(p=0.051), \chi^{2} / \mathrm{DF}=2.204, \mathrm{GFI}=0.961$, AGFI $=0.883$, $\mathrm{TLI}=0.968, \mathrm{CFI}=0.984, \mathrm{RMSEA}=0.102$.

Table 2. Integration practices with suppliers and customers: Confirmatory Factor Analysis.

\begin{tabular}{lcc}
\hline \multicolumn{1}{c}{ Environmental Management Integration Practices } & \multicolumn{1}{c}{ Confirmatory Factor Analysis } \\
\cline { 2 - 3 } & Suppliers & Customers \\
\hline $\begin{array}{l}\text { We develop a mutual understanding of responsibilities regarding } \\
\text { environmental management with our partners. }\end{array}$ & 0.91 & 0.85 \\
$\begin{array}{l}\text { We work together with our partners to reduce environmental impact of } \\
\text { our products and activities. }\end{array}$ & 0.96 & 0.92 \\
$\begin{array}{l}\text { We require (or we are required) environmental certifications to (by) our } \\
\text { partners (e.g., ISO 14001). }\end{array}$ & 0.67 & 0.74 \\
$\begin{array}{l}\text { We interchange environmental technical advice with our partners to meet } \\
\text { environmental criteria. }\end{array}$ & 0.75 & 0.82 \\
$\begin{array}{l}\text { We require our partners to use environmental packaging (or we are } \\
\text { required by our partners to use environmental packaging). }\end{array}$ & 0.62 & 0.74 \\
\hline
\end{tabular}

\subsubsection{Independent Variable}

\section{Operational Performance}

Operational performance was defined and measured by a combination of multi-item scales from others works that analysed operational performance in SC [8]. This study has used the four main components of organizational performance found in the literature (cost, quality, delivery and flexibility), through eight questions. Eight questions were asked about operational performance relative to the main competitor, and all of them were measured using questions with a Likert scale of 1 to 5 . Score 1 indicates that the respondent disagrees strongly with the statement and score 5 indicates that the respondent fully agrees with the statement. The measure for operational performance was obtained through the average of the responses of the items.

The relationships hypothesised were investigated using multiple regression analysis (Table 4). Model 1 includes the control variables, Model 2 includes the control variables and practices with suppliers, Model 3 includes the control variables and practices with customers and finally, Model 4 includes control variables and integrative practices, corresponding to Step 3 of the construction of the measure for the joint adoption of practices with suppliers and customers.

\section{Results}

The values presented for the study variables were computed by averaging the items in the scales. The correlations are presented in Table 3 for the relationship between green practices with suppliers and operational performance, for the relationship between green practices with customers and operational performance, for the relationship between integrative practices with suppliers and 
customers and operational performance. Correlation coefficients are positive and significant at 0.01 for all variable pairings.

Table 3. Correlation matrix for green practices with suppliers and customers and operational performance.

\begin{tabular}{ccccc}
\hline Correlations & $\mathbf{1}$ & $\mathbf{2}$ & $\mathbf{3}$ & $\mathbf{4}$ \\
\hline Operational performance (1) & - & & & \\
EM practices with suppliers (2) & $0.264^{* *}$ & - & & \\
EM practices with customers (3) & $0.402^{* *}$ & $0.774^{* *}$ & - & \\
Balanced up-down EM practices (4) & $0.391^{* *}$ & $0.855^{* *}$ & $0.902^{* *}$ & - \\
\hline
\end{tabular}

Notes: ${ }^{* *}$ Correlation is significant at the 0.01 level. Abbreviations: EM, environmental management.

Table 4 shows the results obtained through multiple regression using GSCM practices with suppliers and customers as an independent variable and the items considered for operational performance as a dependent variable. As expected, all the hypotheses proposed in this work on the relationship between GSCM practices with suppliers and/or customers and operational performance have been confirmed. As shown in Table 4, GSCM practices with suppliers (H1) and with customers (H2) obtained a positive and significant coefficient at 95\%, and GSCM practices with suppliers and customers (H3) obtained a positive and significant coefficient at $99 \%$. Moreover, the control variable "number of customers" obtained a positive and significant coefficient in the three models' results.

Table 4. Estimations results with multiple regression method.

\begin{tabular}{|c|c|c|c|c|}
\hline \multicolumn{5}{|c|}{ Independent Variable: Operational Performance } \\
\hline (Constant) & $2.916^{* * *}$ & $2.739 * * *$ & $2.418^{* * *}$ & $2.235^{* * *}$ \\
\hline Textile Sector & 0.163 & 0.135 & 0.180 & 0.134 \\
\hline Chemical Sector & -0.113 & -0.117 & -0.026 & -0.071 \\
\hline Rubber Sector & -0.082 & -0.077 & -0.007 & -0.066 \\
\hline Number of Suppliers & 0.115 & 0.094 & 0.039 & 0.054 \\
\hline Direct_SC & 0.073 & 0.067 & 0.035 & 0.048 \\
\hline Components_SC & 0.070 & 0.087 & 0.018 & 0.063 \\
\hline Sell to others_SC & 0.066 & 0.074 & 0.024 & 0.051 \\
\hline Size (Total assets) & 0.019 & -0.010 & 0.017 & -0.005 \\
\hline Time & 0.153 & 0.132 & $0.154^{+}$ & 0.136 \\
\hline $\mathrm{F}$ & $1.806^{+}$ & $2.061 *$ & $3.059^{* * *}$ & $2.754^{* * *}$ \\
\hline$\Delta \mathrm{F}$ & - & 0.255 & 1.253 & 0.948 \\
\hline $\mathrm{R}^{2}$ & 0.172 & 0.206 & 0.279 & 0.258 \\
\hline
\end{tabular}

Notes: ${ }^{* * *} p<0.001 ;{ }^{* *} p<0.01 ;{ }^{*} p<0.05 ;^{+} p<0.1$; Abbreviations: CV, control variable; SC, Supply Chain; F, F-test; $\Delta \mathrm{F}$, incremental F-test; $R^{2}$, coefficient of determination.

\section{Discussion of Results}

This study intends to investigate the relationship of environmental practices developed with customers, suppliers and with suppliers and customers together in operational performance. The objective of the research is to investigate the impact of adopting environmental practices on operational performance. The study found that the adoption of environmental practices with suppliers alone, with customers and in conjunction with both suppliers and customers has a major positive impact on organizational operational performance. The results confirm the three hypotheses formulated in this study: the adoption of GSCM practices with suppliers (H1) or customers (H2) separately and the balanced adoption of GSCM practices with both suppliers and customers (H3) has operational benefits for organizations. It has also been observed that the coefficients obtained in the analysis of 
the relationship between green practices with customers are higher than the coefficients obtained for suppliers alone.

These results may reflect the company's tendency to consider environmental customer alliances as more important because they are the ones that guide the steps toward the adoption of green practices in companies. This argument is supported by the literature that reports a positive empirical relationship between the focus on market-oriented knowledge about customers and competitors and financial and environmental performance [60]. In addition, [61] point out that Chinese companies have recently begun to adopt a market orientation strategy as a means of surviving the intensification of competition. This may explain the finding that cooperation with customers is strongly associated with operational performance.

The results also suggest that the more environmental practices are integrated into the mutual understanding of environmental responsibilities and working together with suppliers and customers to reduce impact, the greater the operational gains, such as reducing the time needed to design and/or manufacture environmentally friendly products, because suppliers will be aware of the criteria required to reduce the impact that the input or material they produce generates as well as ensure the customers' environmental requirements will be met.

With regard to the requirement of environmental certification, the results are related to delivery, quality and cost, since the requirement of environmental certifications with suppliers and customers is related to cost reduction, shorter delivery times and better product quality associated with the implementation of ISO 14000 standards, which provide a framework for environmental management systems [62]. The process of implementing an environmental certification must be carried out by independent institutions and, on its own, already brings several improvements to the company with the adoption of standardised processes. It even facilitates the company's support of the so-called "continuous improvement culture". Undeniably, the requirement of an environmental certification of the partners involved in the SC tends to bring benefits to the performance of a company, and in this case, these benefits arise because the implementation of certification systems aims to encourage environmental planning across the organization's range of activities: from the acquisition of raw materials to the distribution of the product, establishing and maintaining appropriate communication with relevant internal and external parties and providing resources, including training, in order to achieve targeted levels of performance on an ongoing basis, among other objectives.

The results of the study highlight that environmental practices involving the use of sustainable packaging also have an impact on operating results. The use of eco-friendly packaging involves reusable packaging or racks that are more impact resistant, reducing product damage during transport [8]. Moreover, reusable packaging reduces product defects and maintains product quality during shipping. Another positive effect of this practice is that reusable racks are used to deliver the materials directly to the assembly line, acting as a Kanban, and thus improving system efficiency and reducing lead time. This result follows on from previous research that stated that good environmental performance leads to superior product quality [63].

In summary, all three practices performed with suppliers alone, customers alone and with both suppliers and customers showed a positive effect on operating results. This indicates that, in general, Brazilian companies value the business benefits of environmental management practices as key criteria for adopting sustainable practices of supply chain management with both suppliers and customers. Thus, as well as companies gaining reputation for adopting environmental practices, it also has benefits that increase the efficiency of SC management.

\section{Managerial Implications}

This research provides indications for managers who seek to implement environmental practices as they could improve operational performance and even supply chain performance through these. Given the growing attention paid by leading global managers to the adoption and implementation of corporate environmental strategies, it is important that they understand key green practices that 
affect operational performance. Practices developed with suppliers such as mutual understanding of environmental responsibilities and working together to solve environmental problems and share know-how can help develop unique environmental competencies by enhancing the value chain. These practices may involve awareness-raising seminars on the importance of cleaner production, as well as guidance from suppliers to set up the environmental programs that need to be developed.

In similar fashion, customer practices can improve environmental capabilities as well as corporate reputation and thus help the company gain greater market share. Mutual understanding in this case may be accompanied by the provision of information on ecological issues concerning products and production methods. Other practices are also important when developed along with customers, such as improvement of packaging, eco-labelling, recovery of end-of-life products, use of environmentally friendly transport and packaging collection.

In relation to environmental certifications, ISO standards can help to develop unique organizational capabilities that have not been captured by other measures adopted by the organization. The requirement for environmental certification ensures the commitment of companies to continuously improve environmental management systems, facilitating the choice of suppliers through environmental criteria. However, at this point, it is necessary to verify the reliability of this instrument, eliminating doubts about its efficacy and reducing the possibility of adopting it in a symbolic behaviour [64].

Although this study does not consider internal environmental management practices, it is equally important that they be consolidated-practices in which both top management and others are committed to and aligned with the environmental objectives in order to strengthen a company's ability to communicate the environmental performance and impact of their products $[9,11]$.

Thus, managers who can understand the supplier-customer relationship and the need for environmental management in companies need to consider external green integration as a critical factor in the implementation of an effective green supply chain management system. In addition, a company can achieve multiple objectives by combining several different green practices, simultaneously leading to sustainable value for all involved.

\section{Impact on the Sectors Studied}

The mutual understanding of environmental responsibility can be understood as the joint analysis about what inputs are needed to produce the product and the impacts that the latter produces on the environment. Life cycle analysis is used to understand product durability and find solutions to reduce obsolescence and increase the life cycle using eco-efficient features. From this, companies develop products and processes that are cleaner, achieve product performance and meet the customers' requirements. In addition, assessment and reporting that describe environmental performance by suppliers and customers can create relationships of trust and commitment to identify and develop established environmental objectives.

One of the sectors analysed was the paper industry, and the mutual understanding in this type of industry is through the identification of environmental impacts, such as deforestation and potential loss of biodiversity, emissions to the atmosphere and water during pulp manufacture and paper, use of chemicals, and generation of waste during manufacture, such as waste and sludge. Through the understanding and environmental responsibilities of the partners involved in the papermaking supply chain, the possible solutions would be to certify the origin of the fibre, which must be $100 \%$ recycled or from sustainably managed forests; (APEO), to establish criteria for the use of hazardous substances in softeners, lotions, perfumers and additives at the production stage and to set up a production waste management system.

Working together to reduce the impact generated by environmental activities through, for example, investment in research and innovation is also an important part of environmental integration, in which it enables the identification of problems and solutions and leads to the launch of new products. An example of this is the discovery of polymer substitution in the plastics industry, which is difficult to disintegrate when recycled, or the decrease in the use of water in the process of dyeing fabrics. 
The requirement for an environmental certification, such as ISO 14001, allows us to work with companies that are respectful of the environment, since the standard requires a commitment to the continuous improvement of environmental management systems, helping companies to use raw materials efficiently, and thus reducing costs (unit cost on operational performance).

Specifying the required environmental criteria is vital in order for environmental integration to take place. Criteria for compliance with technical standards, eco-labels (and also the use of environmentally responsible packaging), production and processing methods, performance or functional requirements can be established so that the environmental objectives in the integration process are achieved. It is even possible to adopt strategies for implementation, follow-up and review, through outsourced teams that are trained and that carry out environmental process audits.

In order for environmental integration to take place, it is necessary for suppliers to adequately meet the environmental requirements requested by their customers, taking into account the satisfaction of all parties involved in the process.

In addition to the operational gains through the adoption of green practices, it is still possible and imperative to achieve a good reputation in front of the final consumers and society, especially in those industries where their activities are more visible in the degradation of the environment such as the agricultural industry, paper and plastic.

\section{Conclusions}

The objective of this work was to analyse the effect of adopting GSCM practices with suppliers and customers on operational performance in Brazilian manufacturing companies, and especially, to verify that this relationship is stronger when green practices are adopted jointly with suppliers and customers. In other words, to check if the adoption of environmental practices in a balanced way with suppliers and customers in green practices improves operational performance in eight items, namely: performance of products, unit cost, product quality, customer support, time needed, capacity to meet customers' requirements, pace of new product launching and flexibility to adapt to demand.

The results obtained support the three hypotheses formulated, whereby the adoption of GSCM practices developed by the company and suppliers (H1) or customers (H2) positively impacts on operational performance, and similarly, when practices are developed jointly with suppliers and customers (H3) there are operational benefits.

The results obtained in this study are consistent with previous studies that have found a positive relationship between green practices and performance $[11,52,65]$. However, this study has extended the literature by measuring green practices in a different context to most research: the Brazilian context, concluding that the practices described have a positive influence on performance. This is an important finding for managers who are considering implementing green practices or looking for ways to improve performance. The results reveal the importance of establishing environmental strategies with SC partners, as green practices are adopted to respond to regulatory or social pressures and may bring operational benefits to the manufacturing industries studied. It is also a means to achieve customer satisfaction with respect to delivery and quality by adapting to changes in demand, as well as reducing inventory levels [11].

The results further suggest that to improve operational performance, companies need to develop practices directly with suppliers and customers, and one option for this is the use of information systems to monitor whether parties are meeting agreed targets and agreements. In addition, the company can make use of specific environmental management systems, such as the Environmental Management Information System (EMIS), which has a relevant role in the processing of environmental information available in the company [66]. Green practices are also expected to be part of the company's business strategy as companies will be encouraged to adopt green practices due to PNRS, which obliges them to implement practices that guarantee environmental management in every productive process, but because it is a recently established policy, companies are still adapting to these practices. 
Another important contribution here is, to the best of our knowledge regarding integration management literature, that there is no measure that considers the adoption of integration practices in a balanced way between suppliers and customers. Many authors consider joint integration according to the measure used by [10], which uses quartiles to conceptualise integration through its direction and extension (for customers and/or suppliers), while other studies deal with integration with suppliers and customers separately. To conduct the analysis of the joint adoption of practices, we have created a measure of balanced up-down EM practices between suppliers and customers, rather than considering integration with suppliers or customers. Our measure can serve as a basis for future studies in other samples or geographical contexts aimed at analysing a company's integration with suppliers and customers.

Our work has certain limitations, one of which is the use of the questionnaire as an instrument of data collection. Many companies refused to answer the questionnaire, which did not allow us to achieve a greater number of completed questionnaires. In addition, the use of only one data source, namely, the questionnaire, is also a limitation, and the data cannot be compared with other sources. Future research may focus on expanding the sample, expanding the sectors studied and conducting analyses by sectors, identifying which green practices are developed most in each sector. The items and measures used may also serve as a basis to be applied to another population and make comparisons, identifying similarities and singling out new opportunities in GSCM in industries. In addition, other measures can be included, such as green purchasing, eco-design in collaboration with partners and the identification of individuals in the partners' team to develop efficient green practices. Moreover, the use of other ways of measuring organisational performance, such as financial performance, could expand the results found in this research. We hope our results will contribute to the momentum of SCM in developing countries and encourage research within this scenario.

Author Contributions: This work is part of the research of H.S., supervised by G.L. and J.G.-B. J.G.-B. and G.L. provided the key ideas for the conceptual framework and hypotheses. H.S. designed and performed the questionnaire. The preliminary draft was writing and prepared by H.S. and reviewed by his co-author G.L.

Funding: This research has been exclusively supported by public funding. H.S. acknowledges the support of the CAPES by grants 588/2014-08.

Conflicts of Interest: The authors declare no conflict of interest. The funders had no role in the design of the study; in the collection, analyses or interpretation of data; in the writing of the manuscript or in the decision to publish the results.

\section{References}

1. Simatupang, T.M.; Sridharan, R. An integrative framework for supply chain collaboration. Int. J. Logistig. Manag. 2005, 16, 257-274. [CrossRef]

2. Lambert, D.M.; Cooper, M.C. Issues in supply chain management. Ind. Market. Manag. 2000, 29, 65-83. [CrossRef]

3. Wisner, J.D.; Tan, K.C. Supply chain management and its impact on purchasing. J. Supply Chain Manag. 2000, 36, 33-42. [CrossRef]

4. Zhao, X.; Huo, B.; Flynn, B.B.; Yeung, J.H.Y. The impact of power and relationship commitment on the integration between manufacturers and customers in a supply chain. J. Oper. Manag. 2008, 26, 368-388. [CrossRef]

5. Flynn, B.B.; Huo, B.; Zhao, X. The impact of supply chain integration on performance: A contingency and configuration approach. J. Oper. Manag. 2010, 28, 58-71. [CrossRef]

6. Lee, H.L.; Padmanabhan, V.; Whang, S. Information distortion in a supply chain: The bullwhip effect. Manag. Sci. 1997, 43, 546-558. [CrossRef]

7. Handfield, R.; Sroufe, R.; Walton, S. Integrating environmental management and supply chain strategies. Bus. Strategy Environ. 2005, 14, 1-19. [CrossRef]

8. Vachon, S.; Klassen, R.D. Environmental management and manufacturing performance: The role of collaboration in the supply chain. Int. J. Prod. Econ. 2008, 111, 299-315. [CrossRef] 
9. Zhu, Q.; Sarkis, J. Relationships between operational practices and performance among early adopters of green supply chain management practices in Chinese manufacturing enterprises. J. Oper. Manag. 2004, 22, 265-289. [CrossRef]

10. Frohlich, M.T.; Westbrook, R. Arcs of integration: An international study of supply chain strategies. J. Oper. Manag. 2001, 19, 185-200. [CrossRef]

11. Green, K.W.; Zelbst, P.J.; Meacham, J.; Bhadauria, V.S. Green supply chain management practices: Impact on performance. Supply Chain Manag. 2012, 17, 290-305. [CrossRef]

12. Estampe, D.; Lamouri, S.; Paris, J.-L.; Brahim-Djelloul, S. A framework for analysing supply chain performance evaluation models. Int. J. Prod. Econ. 2013, 142, 247-258. [CrossRef]

13. Ministério do Meio Ambiente. Available online: http://www.mma.gov.br (accessed on 11 March 2019).

14. International Monetary Fund. Available online: https://www.imf.org (accessed on 9 October 2018).

15. Fritz, M.M.C.; Silva, M.E. Exploring supply chain sustainability research in Latin America. Int. J. Phys. Distr. Logist. 2018, 48, 818-841. [CrossRef]

16. Laosirihongthong, T.; Adebanjo, D.; Tan, K.C. Green supply chain management practices and performance. Ind. Manag. Data Syst. 2013, 113, 1088-1109. [CrossRef]

17. Chiou, T.-Y.; Chan, H.K.; Lettice, F.; Chung, S.H. The influence of greening the suppliers and green innovation on environmental performance and competitive advantage in Taiwan. Transp. Res. Part E Logist. Transp. Rev. 2011, 47, 822-836. [CrossRef]

18. Tsai, M.-T.; Chuang, L.-M.; Chao, S.-T.; Chang, H.-P. The effects assessment of firm environmental strategy and customer environmental conscious on green product development. Environ. Monit. Assess. 2012, 184, 4435-4447. [CrossRef]

19. Carter, C.R.; Easton, P.L. Sustainable supply chain management: Evolution and future directions. Int. J. Phys. Distr. Logist. 2011, 41, 46-62. [CrossRef]

20. Seuring, S. Integrated chain management and supply chain management comparative analysis and illustrative cases. J. Clean. Prod. 2004, 12, 1059-1071. [CrossRef]

21. Bowen, F.; Cousins, P.; Lamming, R.; Faruk, A. Horses for courses: Explaining the gap between the theory and practice of green supply. In Greening the Supply Chain; Sarkis, J., Ed.; Springer: London, UK, 2006; pp. 151-172.

22. Holt, D.; Rao, P. Do green supply chains lead to competitiveness and economic performance? Int. J. Oper. Prod. Manag. 2005, 25, 898-916. [CrossRef]

23. Chen, Y.J.; Sheu, J.-B. Environmental-regulation pricing strategies for green supply chain management. Transp. Res. Part E Logist. Transp. Rev. 2009, 45, 667-677. [CrossRef]

24. De, A.; Choudhary, A.; Tiwari, M.K. Multiobjective approach for sustainable ship routing and scheduling with draft restrictions. IEEE Trans. Eng. Manag. 2019, 66, 35-51. [CrossRef]

25. De, A.; Wang, J.; Tiwari, M.K. Hybridizing basic variable neighborhood search with particle swarm optimization for solving sustainable ship routing and bunker management problem. IEEE Trans. Intell. Transp. Syst. 2019, 1-12. [CrossRef]

26. Chanintrakul, P.; Mondragon, A.E.C.; Lalwani, C.; Wong, C.Y. Reverse logistics network design: A state-of-the-art literature review. Int. J. Bus. Perform. Supply Chain Model. 2009, 1, 61-81. [CrossRef]

27. Pochampally, K.K.; Gupta, S.M.; Govindan, K. Metrics for performance measurement of a reverse/closed-loop supply chain. Int. J. Bus. Perform. Supply Chain Model. 2009, 1, 8-32. [CrossRef]

28. Shrivastava, P.; Hart, S. Creating sustainable corporations. Bus. Strategy Environ. 1995, 4, 154-165. [CrossRef]

29. Simpson, D.; Samson, D. Environmental strategy and low waste operations: Exploring complementarities. Bus. Strategy Environ. 2008, 19, 104-118. [CrossRef]

30. Swink, M.; Narasimhan, R.; Wang, C. Managing beyond the factory walls: Effects of four types of strategic integration on manufacturing plant performance. J. Oper. Manag. 2007, 25, 148-164. [CrossRef]

31. Wong, C.Y.; Boon-itt, S.; Wong, C.W.Y. The contingency effects of environmental uncertainty on the relationship between supply chain integration and operational performance. J. Oper. Manag. 2011, 29, 604-615. [CrossRef]

32. Zhu, Q.; Sarkis, J.; Lai, K.-H. Confirmation of a measurement model for green supply chain management practices implementation. Int. J. Prod. Econ. 2008, 111, 261-273. [CrossRef]

33. Linton, J.D.; Klassen, R.; Jayaraman, V. Sustainable supply chains: An introduction. J. Oper. Manag. 2007, 25, 1075-1082. [CrossRef] 
34. Lee, K.-H.; Kim, J.-W. Integrating suppliers into green product innovation development: An empirical case study in the semiconductor industry. Bus. Strategy Environ. 2011, 20, 527-538. [CrossRef]

35. Sharfman, M.P.; Shaft, T.M.; Anex, R.P. The road to cooperative supply-chain environmental management: Trust and uncertainty among pro-active firms. Bus. Strategy Environ. 2007, 18, 1-13. [CrossRef]

36. Kerr, I.R. Leadership strategies for sustainable SME operation. Bus. Strategy Environ. 2005, 15, 30-39. [CrossRef]

37. Florida, R. Lean and green: The move to environmentally conscious manufacturing. Calif. Manag. Rev. 1996, 39, 80-105. [CrossRef]

38. Rothenberg, S.; Geffen, C.A. Suppliers and environmental innovation: The automotive paint process. Int. J. Oper. Prod. Manag. 2000, 20, 166-186. [CrossRef]

39. Christmann, P.; Taylor, G. Firm self-regulation through international certifiable standards: Determinants of symbolic versus substantive implementation. J. Int. Bus. Stud. 2006, 37, 863-878. [CrossRef]

40. Min, H.; Galle, W.P. Green purchasing practices of US firms. Int. J. Oper. Prod. Manag. 2001, 21, $1222-1238$. [CrossRef]

41. Rondinelli, D.A.; Vastag, G. Global corporate environmental management practices at Alcoa. Corp. Environ. Strategy 2000, 7, 289-297. [CrossRef]

42. Sustainable Brands. Available online: https://sustainablebrands.com (accessed on 26 November 2018).

43. ISO. Available online: https://www.iso.org/home.html (accessed on 15 November 2018).

44. Ann, G.E.; Wahid, N.A.; Zailani, S. A study on the impact of environmental management system (EMS) certification towards firms' performance in Malaysia. Manag. Environ. Qual. Int. J. 2006, 17, 73-93. [CrossRef]

45. González-Benito, J.; González-Benito, O. An analysis of the relationship between environmental motivations and ISO14001 certification. Br. J. Manag. 2005, 16, 133-148. [CrossRef]

46. Thompson, R.C.; Moore, C.J.; vom Saal, F.S.; Swan, S.H. Plastics, the environment and human health: Current consensus and future trends. Philos. Trans. R. Soc. B 2009, 364, 2153-2166. [CrossRef]

47. de Haes, H.A.U.; Snoo, G.R.d. Environmental certification. Int. J. Life Cycle Assess. 1996, 1, $168-170$. [CrossRef]

48. Choi, D.; Hwang, T. The impact of green supply chain management practices on firm performance: The role of collaborative capability. Oper. Manag. Res. 2015, 8, 69-83. [CrossRef]

49. Hellström, D.; Saghir, M. Packaging and logistics interactions in retail supply chains. Packag. Technol. Sci. 2006, 20, 197-216. [CrossRef]

50. Prado-Prado, J.C.; García-Arca, J.; Garrido, A.T.G.-P. “Packaging logistics”: Promoting sustainable efficiency in supply chains. Int. J. Phys. Distrib. Logist. 2014, 44, 325-346. [CrossRef]

51. Grönman, K.; Soukka, R.; Järvi-Kääriäinen, T.; Katajajuuri, J.-M.; Kuisma, M.; Koivupuro, H.-K.; Ollila, M.; Pitkänen, M.; Miettinen, O.; Silvenius, F.; et al. Framework for sustainable food packaging design. Packag. Technol. Sci. 2012, 26, 187-200. [CrossRef]

52. Azevedo, S.G.; Carvalho, H.; Machado, V.C. The influence of green practices on supply chain performance: A case study approach. Transp. Res. Part E Logist. Transp. Rev. 2011, 47, 850-871. [CrossRef]

53. Zailani, S.; Jeyaraman, K.; Vengadasan, G.; Premkumar, R. Sustainable supply chain management (SSCM) in Malaysia: A survey. Int. J. Prod. Econ. 2012, 140, 330-340. [CrossRef]

54. Miroshnychenko, I.; Barontini, R.; Testa, F. Green practices and financial performance: A global outlook. J. Clean. Prod. 2017, 147, 340-351. [CrossRef]

55. Woo, C.; Kim, M.G.; Chung, Y.; Rho, J.J. Suppliers' communication capability and external green integration for green and financial performance in Korean construction industry. J. Clean. Prod. 2016, 112, 483-493. [CrossRef]

56. Dillman, D.A.; Phelps, G.; Tortora, R.; Swift, K.; Kohrell, J.; Berck, J.; Messer, B.L. Response rate and measurement differences in mixed-mode surveys using mail, telephone, interactive voice response (IVR) and the Internet. Soc. Sci. Res. 2009, 38, 1-18. [CrossRef]

57. Paxson, C.H. Using weather variability to estimate the response of savings to transitory income in Thailand. Am. Econ. Rev. 1992, 82, 15-33.

58. Jarvis, C.B.; MacKenzie, S.B.; Podsakoff, P.M. A critical review of construct indicators and measurement model misspecification in marketing and consumer research. J. Consum. Res. 2003, 30, 199-218. [CrossRef]

59. Hair, J.F., Jr.; Anderson, R.E.; Tatham, R.L.; Black, W.C. Multivariate Data Analysis, 4th ed.; Prentice Hall: Englewood Cliffs, NJ, USA, 1995; ISBN 0-02-349020-9. 
60. Chen, Y.; Tang, G.; Jin, J.; Li, J.; Paillé, P. linking market orientation and environmental performance: The influence of environmental strategy, employee's environmental involvement, and environmental product quality. J. Bus. Ethics 2015, 127, 479-500. [CrossRef]

61. Zhu, Q.; Sarkis, J.; Lai, K.-h.; Geng, Y. The role of organizational size in the adoption of green supply chain management practices in China. Corp. Soc. Responsib. Environ. Manag. 2008, 15, 322-337. [CrossRef]

62. Hanson, J.D.; Melnyk, S.A.; Calantone, R.J. Core values and environmental management: A strong inference approach. Greener Manag. Int. 2004, 46, 29-40. [CrossRef]

63. Pil, F.K.; Rothenberg, S. Environmental performance as a driver of superior quality. Prod. Oper. Manag. 2009, 12, 404-415. [CrossRef]

64. Testa, F.; Boiral, O.; Iraldo, F. Internalization of environmental practices and institutional complexity: Can stakeholders pressures encourage greenwashing? J. Bus. Ethics 2018, 147, 287-307. [CrossRef]

65. Chan, K.M.A.; Satterfield, T.; Goldstein, J. Rethinking ecosystem services to better address and navigate cultural values. Ecol. Econ. 2012, 74, 8-18. [CrossRef]

66. El-Gayar, O.; Fritz, B.D. Environmental management information systems (EMIS) for sustainable development: A conceptual overview. Commun. Assoc. Inf. Syst. 2006, 17, 34. [CrossRef]

(C) 2019 by the authors. Licensee MDPI, Basel, Switzerland. This article is an open access article distributed under the terms and conditions of the Creative Commons Attribution (CC BY) license (http://creativecommons.org/licenses/by/4.0/). 